\title{
Microbiotests in aquatic toxicology: the way forward
}

\author{
C. Blaise ${ }^{1}$ \& J.-F. Férard ${ }^{2}$ \\ ${ }^{1}$ Environnement Canada, Montréal, Canada \\ ${ }^{2}$ Université de Metz, France
}

\begin{abstract}
The industrial revolution has driven the need for ecotoxicology and shaped its evolution. Indeed, the increased use and transformation of (non)renewable resources for over a century to benefit mankind have had a downside and created a plethora of contaminants harmful to the receiving environments. With time, we have gone from an age of darkness in the 1950s (i.e., diagnostic ignorance in terms of recognizing and dealing with contamination) to one of enlightenment as the $21^{\text {st }}$ century unfolds (i.e., use of tools and strategies to identify and correct environmental pollutions). Effects measurements, reflected by toxicity testing conducted at different levels of biological organization, have proven especially useful to achieve proper hazard/risk assessments of contaminants. Knowing why toxicity testing has been conducted over the past decades to protect and conserve freshwater environments is also essential to grasp the importance and breadth of this field. For this purpose, we have recently reviewed a substantial number of articles describing numerous bioanalytical endeavours undertaken to comprehend toxic effects associated with the discharge of xenobiotics to aquatic environments. Scrutiny of publications identified in our literature search has enabled us to uncover the various ways in which laboratory toxicity tests have been applied, many of which are small-scale in nature. In essence, freshwater toxicity testing has significantly focussed on liquid (complex environmental samples, chemical and biological contaminants) and solid media (sediments) assessment. For both media, miscellaneous studies/initiatives linked to toxicity testing applications have again promoted the development, validation, refinement and use of toxicity testing procedures. Bioassays are clearly an essential component of environmental management programs and several small-scale tests (microbiotests) can be employed to generate cost-effective toxicity data that assist decision-making.

Keywords: microbiotests, aquatic toxicology, effects measurements, freshwater toxicity testing, contaminants, evolution of ecotoxicology.
\end{abstract}




\section{Introduction}

Innovations in technology periodically spark changes in human society and drastically transform our way of doing things. The most recent industrial revolution, which began in England as early as the $18^{\text {th }}$ century, spread to most of Europe and elsewhere during the $19^{\text {th }}$ and $20^{\text {th }}$ centuries, and continues onwards to other developing parts of the world to this day, is unquestionably the most significant of modern times. Extensive mechanization, urban concentration of labour and large-scale production of goods and materials from increased use (and transformation) of (non)renewable resources characterize this indefectible quest to enhance the quality of life of Homo sapiens. While human progress is a worthwhile endeavour, unabated industrial growth over time has produced, as its downside, numerous pollution problems for receiving environments of our biosphere.

\section{Ecotoxicological evolution}

With respect to freshwater aquatic environments - the focus of this papergrowing chemical contamination generated by industrial processes eventually led, as we shall see, to the creation of a new discipline of the environmental sciences termed "ecotoxicology".

Figure 1 illustrates, by way of decadal snapshots, how ecotoxicological evolution occurred starting from the middle of the $20^{\text {th }}$ century. Awareness of pollution problems finally began to sink in by the $1950 \mathrm{~s}$ when degraded environments became obvious and decision-makers (depicted by the friendly dinosaur in Fig. 1a) wished to reverse the trend and hoped for a return to more pristine conditions. Because know-how, tools and strategies were simply not available to assess impacted areas, however, curative responses were either limited or ineffective. The 1950s and before could thus be referred to as "the age of darkness" in terms of environmental action.

In developed countries in the 1960s, toxicity testing conducted with fish confirmed that large volumes of wastewaters discharged from various industries and municipalities, as well as specific contaminants (e.g., cadmium, mercury, pesticides), were indeed toxic, very often causing rapid lethal effects on exposed organisms [1]. This decade, in particular, highlighted the intrinsic need for effects-based measurements to properly assess contaminants and certainly merits being remembered as "the beginning of enlightenment" in terms of enhancing basic knowledge on the hazards posed by aquatic contaminants (Fig. 1b).

Owing in part to bioanalytical data amassed in the 1960s demonstrating the adverse effects of point source discharges and their potential (or real) impact on aquatic biota and habitat in some cases, environmental agencies/departments were created in several countries (e.g., U.S. Environmental Protection Agency, Environment Canada, French Environment Department) at the start of the 1970s. Chemical characterization of effluents and regulatory compliance based on both chemical and toxicological parameters soon proved helpful in eradicating acute 

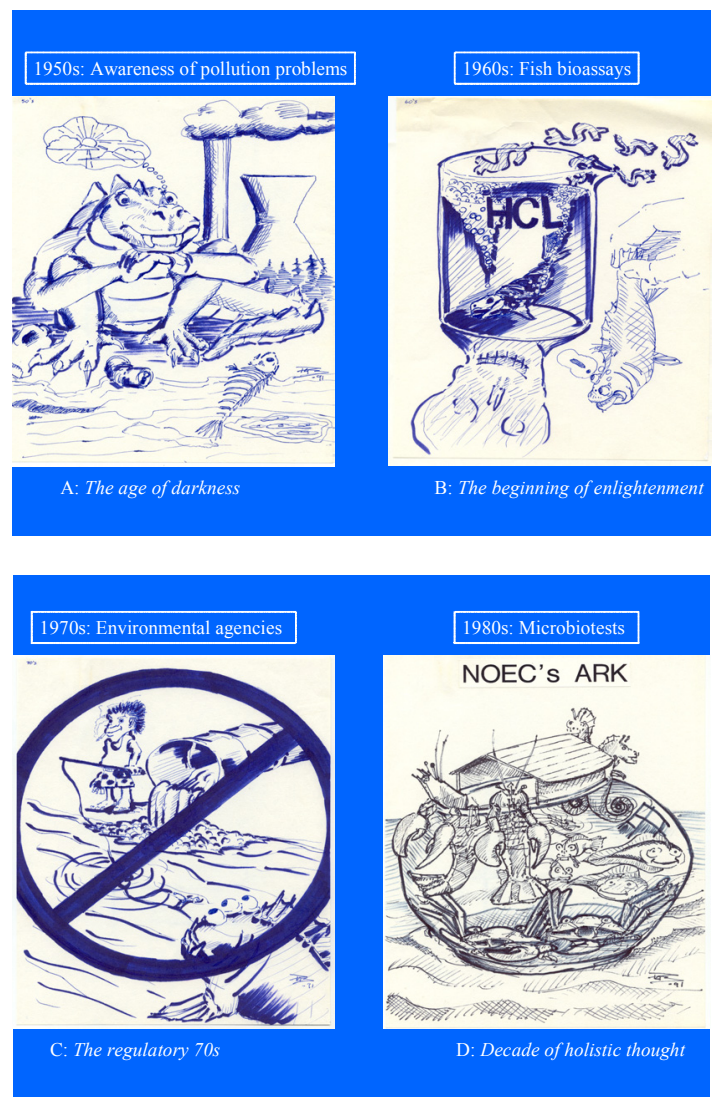

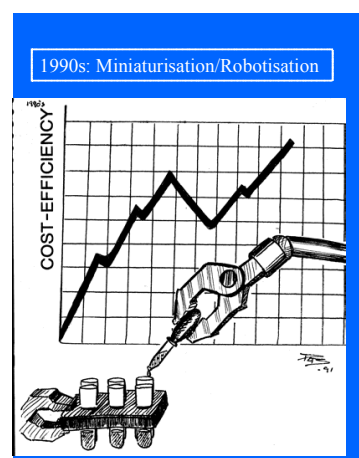

E: The cost-effective 90 's
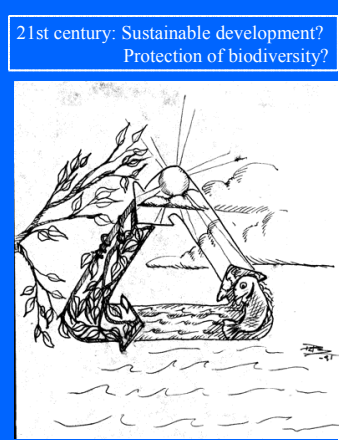

F: The Golden Age?

Figure 1: Ecotoxicological evolution: contaminant pressures trigger the need for effects-based measurements. 
lethal effects from such wastewaters. As a result, fish were once again able to survive in the vicinity of effluent outfalls, but their yet unaddressed chronic (insidious) effects remained a serious concern, as suggested by the three-eyed fish in Fig. 1c. The 1970s can also be remembered as those marking the official birth of the field of ecotoxicology, by and large the study of environmental pollutants and their effects on biota. Essentially a fusion of the words "ecology" and toxicology", the appellation "ecotoxicology", makes its debut in the scientific literature. First reported in France [2], it is soon adopted by several others who propose definitions to specify its scope and breadth [3-5].

Sustained biotesting carried out throughout the 1970s and beyond showed that toxic effects could often be trophic level-specific (e.g., herbicides on photosynthesis of micro-algae) and consequently stimulated the development of acute/chronic toxicity testing at different levels of biological organization. In the 1980s, several small-scale tests (microbiotests) employing bacteria, algae and micro-invertebrates, for example, were used in "battery approaches" in an attempt to circumscribe the full toxic potential of chemicals and environmental samples [6]. This decade clearly popularized microbiotesting and holistic thinking in that integrated biological/chemical strategies were able to identify the species most at risk linked to a particular contaminant or pollution event (Fig. 1d). By protecting the most sensitive life form, all others are indeed secure.

The need for applying cost-effective toxicity tests capable of high throughput became urgent in the 1990s owing to the increasing number of environmental samples requiring assessment (Fig. 1e). Because of the attractive features intrinsic to several microbiotests (e.g., low-volume requirements, miniaturisation and automation potential), microplate-based tests such as the SOS Chromotest were indeed capable of achieving remarkable performances [7].

At the dawn of the $21^{\text {st }}$ century where issues of sustainable development and biodiversity are inextricably interdependent, ecotoxicology, with its tools and strategies which include microbiotesting of xenobiotics, will have a positive role to play in the conservation and protection of aquatic systems. Effects measurements applied internationally to estimate contaminant hazard of (non)point sources of pollution, coupled with effective technology, should provide the cognitive function necessary to drive subsequent curative and preventive actions to ensure clean water for all living creatures including mankind (Fig. 1f). This goal will only be achievable pending concerted efforts of knowledgeable decision-makers on a global scale.

\section{The "cart before the oxen" syndrome}

Attempting to infer effects on biota from chemistry alone is simply a no-no nowadays, but it was once prevalent during a time period (possibly up to 1975) when toxicity tests, still to be developed or applied, had not yet come to the fore. An example of the "cart before the oxen syndrome" in this respect depicting moot management of environmental funds is given by way of the narrative in Table 1. Not so obvious then for environmental managers was to think that thorough chemical scans of complex effluents, which are seldom exhaustive, 
would suffice to report their hazardous status and identify corrective clean-up actions. Knowledge today dictates that a chemical-based approach alone says little on bioavailability and possible interactions of the cocktail of pollutants that can be present in effluent mixtures. Nor does it give information on effects (acute/chronic toxicity, genotoxicity, etc.) or on the trophic level(s) that can be targeted by specific wastewaters.

Table 1: $\quad$ The cart-before-the-oxen-syndrome (see text for details).

An environmental manager, fond of chemical parameters, was mandated to determine the environmental hazard of a particular industrial effluent. $\mathrm{He}$ thus called upon a private laboratory to undertake an exhaustive scan of priority pollutants suspected of being present in the effluent. After spending $25 \mathrm{~K}$ for this study and obtaining chemical data on 50 substances in return, his superior urged him to conclude categorically on the potential impact this wastewater discharge was having on receiving water biota and on the cleanup actions that should be taken. He suddenly realized that he could not infer very much!

- Where did he go wrong?

- What should he have envisaged instead?

This "data rich/information poor" situation can only be offset by contemporary recognition that a combined biological/chemical strategy should be implemented. Indeed, the demonstrated presence of adverse effects by first conducting biological testing will then justify the generation of chemical analysis in an attempt to link specific contaminants to observed effects via validated approaches calling upon toxicity identification evaluations, or TIEs, and toxicity reduction evaluations, or TREs [8]. To be effective, ecotoxicology now thrives on multi-disciplinary partnerships struck with toxicology, chemistry and ecology (and other related fields of science) such that the cart-before-the-oxen-syndrome is rapidly disappearing.

\section{Microbiotests}

Small-scale toxicity testing, an offshoot of aquatic toxicology, blossomed in the 1980 s as development and application of microbiotests began to proliferate owing to an increasing demand for cost-effective tests conducted at various levels of biological organization. Simply defined as the "exposure of a unicellular or small multi-cellular organism to a liquid/solid sample to measure a specific effect" [9], microbiotests are clearly at the forefront in the daily war being waged against contaminants owing to their effective toxicity screening potential. Coupled with other effects-based measurements that include biomarkers and in situ approaches (e.g., biotic indices), ecotoxicological tools can convincingly combine with chemical analysis to identify culprit pollutants responsible for biotic impacts in the laboratory and in the field (Fig. 2). Several 
reliable and relevant small-scale tests exist to appraise both liquid and solid media, although a larger number of methods are presently available to measure toxicity in the former over the latter (Table 2). While representative of applicable micro-scale assays, this list is nevertheless far from exhaustive.

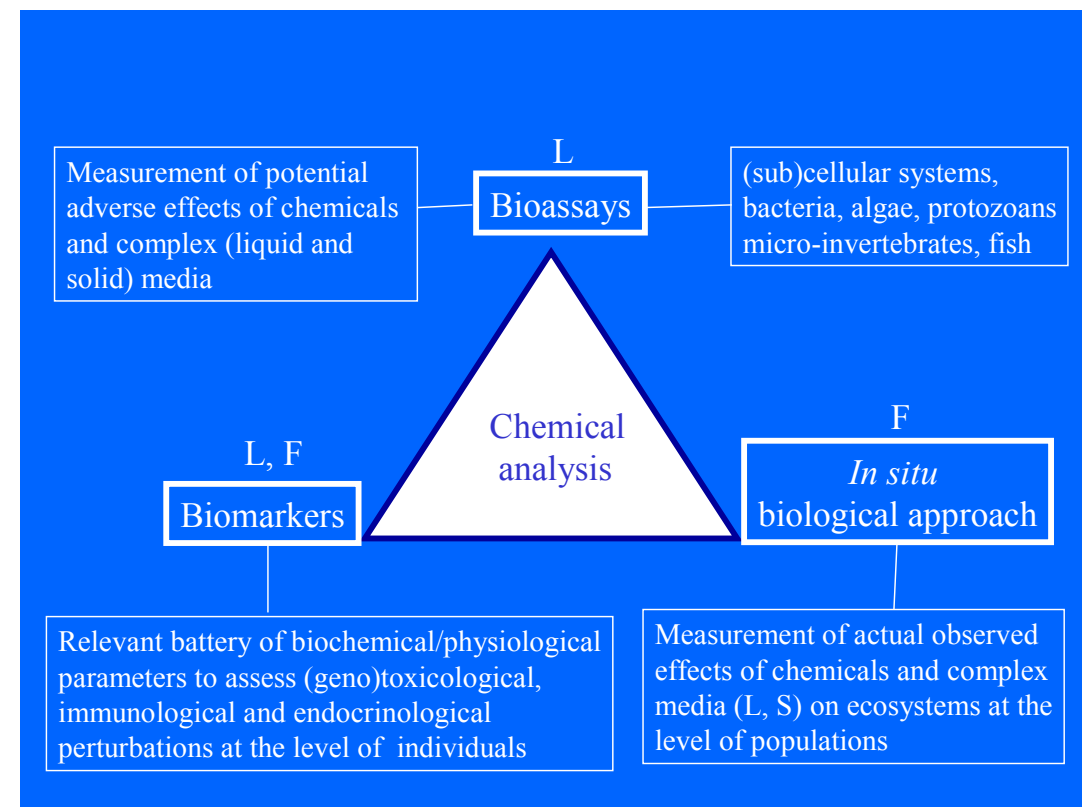

Figure 2: Complementary tools in ecotoxicology for laboratory- (L) or field(F) based studies and their essential link with chemical analysis to establish cause-effect relationships.

\section{Richness of toxicity testing applications}

Published articles in the scientific literature (both primary and grey) spanning over three decades (1970s and beyond) have contributed a wealth of information linked to diverse aspects of toxicity testing. In surveying several databases, we have recently reviewed a substantial number of articles describing numerous bioanalytical endeavours undertaken to comprehend toxic effects associated with the discharge of xenobiotics to aquatic environments [10]. This search enabled us to uncover the various ways in which laboratory toxicity tests have been applied, many of which are small-scale in nature. In essence, freshwater toxicity testing has significantly focussed on liquid (complex environmental samples, chemical and biological contaminants) and solid media (sediments) assessment. For both media, miscellaneous studies/initiatives linked to toxicity testing applications have again promoted the development, validation, refinement and use of toxicity testing procedures (Fig. 3). 
Table 2: Examples of typical (micro)biotests available for freshwater toxicity investigations.

\begin{tabular}{|c|}
\hline Liquid media assessment \\
\hline $\begin{array}{l}\text { Algae: Flask growth inhibition assay [11]; Microplate growth inhibition assay [12]; } \\
\text { Flow cytometric techniques [13] }\end{array}$ \\
\hline Aquatic macrophytes: Lemna minor chronic assay [14] \\
\hline Bacteria: Microtox acute assay [15]; SOS Chromotest [7]; MetPlate [16] \\
\hline $\begin{array}{l}\text { Fish cells: Trout primary hepatocyte cytotoxicity assay [17]; Trout gill cell line } \\
\text { cytotoxicity assay [18] }\end{array}$ \\
\hline $\begin{array}{l}\text { Micro-invertebrates: } T \text {. platyurus acute assay (http://www.microbiotests.be); Hydra } \\
\text { population reproduction assay [19]; D. magna acute/chronic assays [20] }\end{array}$ \\
\hline $\begin{array}{l}\text { Protozoa: } S . \text { ambiguum acute assay }[21] ; \quad T . \\
\text { (http://www.microbiotests.be) }\end{array}$ \\
\hline Solid media assessment \\
\hline Algae: Algal solid phase assay [22]; LuminoTox solid phase assay [23] \\
\hline Bacteria: Microtox acute solid phase assay [24]; SOS Chromotest solid phase assay \\
\hline Micro-invertebrates: $C$. riparius survival and growth assay [26] \\
\hline
\end{tabular}

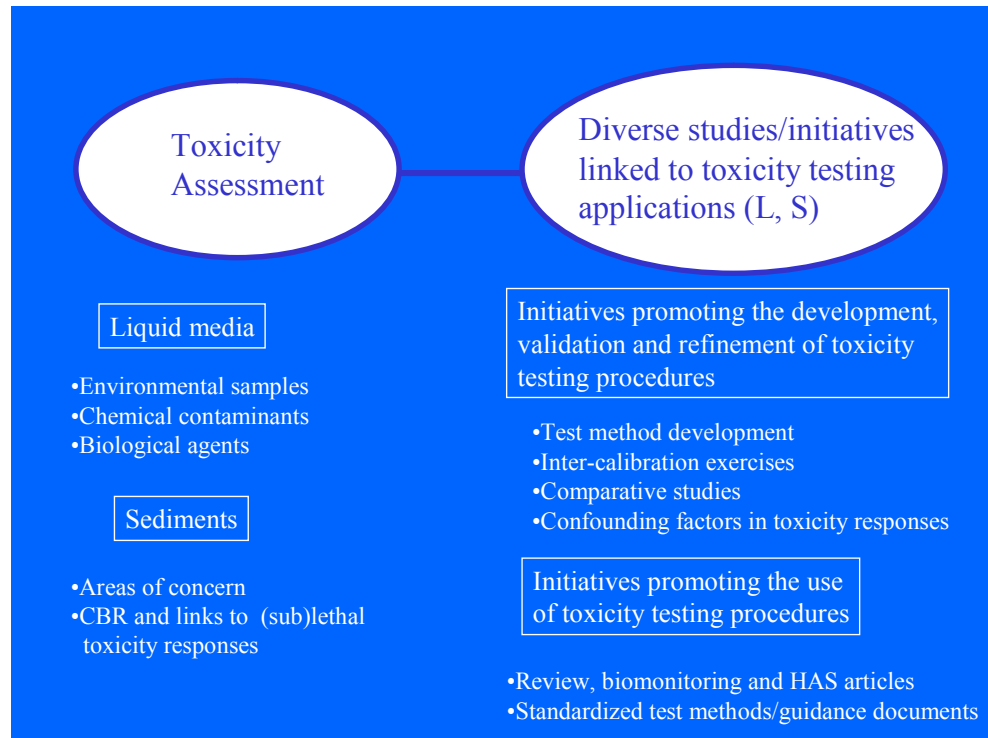

Figure 3: Overview of contemporary toxicity testing: adapted from Blaise and Férard, 2005 [10]. L (liquid media); S (solid media); CRB (critical body residues); HAS (hazard assessment schemes). 


\section{Conclusions}

Adequate assessment of pollutants calls for an effects-based approach complemented by chemical analysis, now an essential cog of the multidisciplinary field of ecotoxicology. Within this combined biological/chemical strategy, toxicity testing can provide key information to guide decisions that will ensure effective protection and conservation of freshwater biota from adverse effects of harmful chemicals. As diagnostic tools of ecotoxicity, bioassays have an important role to play in this respect.

In addition and also owing to their attractive characteristics, several microbiotests are able to confer much needed cost-effectiveness and throughput for appraisal of contaminants. Recent books reporting on the benefits of smallscale testing applications reflect the marked influence of microbiotests and suggest that their popularity and use will grow in the future [28-30].

\section{Acknowledgments}

The authors are indebted to their respective managements (Environment Canada and University of Metz) for supporting this work presented during the "Environmental Toxicology 2006" conference held in Mykonos, Greece, from September 11-13, 2006. The remarkable drawings incorporated in Fig. 1 are those of Patrick Bermingham (Montreal, Quebec, Canada).

\section{References}

[1] Blaise, C., Sergy, G., Wells, P., Bermigham, N. \& van Coillie, R., Biological Testing - Development, Application and Trends in Canadian Environmental protection Laboratories. Toxicity Assessment 3, pp. 385-406. 1988.

[2] Jouany, J. M. Nuisances et Ecologie. Actualités Pharmaceutiques 69, pp. 11-22, 1971.

[3] Butler, G.C. (ed.). Principles of Ecotoxicology, SCOPE series, Volume 12, J. Wiley and Sons: New York, 372 pages. 1978.

[4] Ramade, F. (ed.). Ecotoxicologie. Collection d'écologie, no. 9, Masson éditeur: Paris, pp. 228, 1979.

[5] Moriarty, F. (ed.). Ecotoxicology, the study of pollutants in ecosystems. Academic Press: London/New York, pp. 233, 1983.

[6] Dutka, B. Priority setting of hazards in waters and sediments by proposed ranking scheme and battery of tests approach. Zeitschift für Angewandte Zool. 75, pp. 303-316, 1988.

[7] White, P., Rasmussen, J. \& Blaise, C. A semi-automated, microplate version of the SOS Chromotest for the analysis of complex environmental extracts. Mutation Res. 360, pp. 51-74, 1996.

[8] Novak, L. \& Holtze, K. Overview of toxicity reduction and identification evaluations for use with small-scale tests. Small-scale Freshwater Toxicity 
Investigations, Volume 2, eds. C. Blaise \& J.F. Férard, Springer Publishers Dordrecht, The Netherlands, pp. 169-213. 2005.

[9] Blaise, C., Wells, P. \& Lee, K., Microscale testing in aquatic toxicology: Introduction, historical perspective, and context. Microscale testing in Aquatic Toxicology Advances, Techniques and Practice, eds. P. Wells, K. Lee \& C. Blaise, CRC Lewis Publishers: Boca Raton, Florida, pp. 1-9, 1998.

[10] Blaise, C. \& Férard, J.F., Overview of contemporary toxicity testing. Small-scale Freshwater Toxicity Investigations, Volumes 1 and 2, eds. C. Blaise \& J.F. Férard, Springer Publishers: Dordrecht, The Netherlands, pp. 1-68, 2005

[11] Staveley, J.P. \& Smrchek, J.C. Algal toxicity test. Small-scale Freshwater Toxicity Investigations, Volume 1, eds. C. Blaise and J.F. Férard, Springer Publishers: Dordrecht, The Netherlands, pp. 181-202, 2005.

[12] Blaise, C. \& Vasseur, P., Algal Microplate Toxicity test. Small-scale Freshwater Toxicity Investigations, Volume 1, eds. C. Blaise and J.F. Férard: Springer Publishers: Dordrecht, The Netherlands, pp. 137-179, 2005.

[13] Stauber, J., Franklin, N. \& Adams, M. Microalgal toxicity tests using flow cytometry. Small-scale Freshwater Toxicity Investigations, Volume 1, eds. C. Blaise \& J.F. Férard, Springer Publishers Dordrecht, The Netherlands, pp. 203-241, 2005.

[14] Moody, M. \& Miller, J. Lemna minor growth inhibition test. Small-scale Freshwater Toxicity Investigations, Volume 1, eds. C. Blaise \& J.F. Férard, Springer Publishers: Dordrecht, The Netherlands, pp. 271-298, 2005.

[15] Johnson, B.T. Microtox acute toxicity test. Small-scale Freshwater Toxicity Investigations, Volume 1, eds. C. Blaise \& J.F. Férard, Springer Publishers: Dordrecht, The Netherlands pp. 69-105, 2005.

[16] Bitton, G., Ward, M. \& Dagan, R. Determination of the heavy metal binding capacity (HMBC) of environmental samples. Small-scale Freshwater Toxicity Investigations, Volume 2, eds. C. Blaise and J.F. Férard, Springer Publishers: Dordrecht, The Netherlands, pp. 215-231. 2005.

[17] Gagné, F. Acute toxicity assessment of liquid samples with primary cultures of rainbow trout hepatocytes. Small-scale Freshwater Toxicity Investigations, Volume 1, eds. C. Blaise \& J.F. Férard, Springer Publishers Dordrecht, The Netherlands, pp. 453-472, 2005.

[18] Dayeh, V.R., Schirmer, K, Lee, L.E. \& Bols, N. Rainbow trout gill cell line microplate cytotoxicity test. Small-scale Freshwater Toxicity Investigations, Volume 1, eds. C. Blaise and J.F. Férard, Springer Publishers: Dordrecht, The Netherlands, pp. 473-503. 2005.

[19] Holdway, D. Hydra population reproduction toxicity test method. Smallscale Freshwater Toxicity Investigations, Volume 1, eds. C. Blaise \& J.F. Férard, Springer Publishers Dordrecht, The Netherlands, pp. 395-411, 2005. 
[20] Jonczyk, E. \& Gilron, G. Acute and chronic toxicity testing with Daphnia sp. Small-scale Freshwater Toxicity Investigations, Volume 1, eds. C. Blaise \& J.F. Férard, Springer Publishers: Dordrecht, The Netherlands, pp. 337-393, 2005.

[21] Nalecz-Jawecki, G. Spirostomum ambiguum acute toxicity test. Smallscale Freshwater Toxicity Investigations, Volume 1, eds. C. Blaise \& J.F. Férard, Springer Publishers Dordrecht, The Netherlands, pp. 299-322. 2005.

[22] Blaise, C. \& Ménard, L. A micro-algal solid phase test to assess the toxic potential of freshwater sediments. Water Qual. Res. J. Canada 33, pp. 133-151, 1998.

[23] Dellamatrice, P. Monteiro, R., Blaise, C., Slabbert, J.L., Gagné F. \& Alleau. S. Toxicity Assessment of reference and natural freshwater sediments with the Luminotox assay. Environ. Toxicol. 21(4), 2006 (in press).

[24] Doe, K., Jackman, P., Scroggins, R., McLeay, D. \& Wohlgeshaffen, G. Solid-phase test for sediment toxicity using the luminescent bacterium, Vibrio fischeri. Small-scale Freshwater Toxicity Investigations, Volume 1, eds. C. Blaise \& J.F. Férard, Springer Publishers: Dordrecht, The Netherlands, pp. 107-136. 2005.

[25] Dutka, B., Teichgräber, K. \& Lifshitz, R. A modified SOS-Chromotest procedure to test for genotoxicity and cytotoxicity in sediments directly without extraction. Chemosphere 31, pp. 3273-3289, 1995.

[26] Péry, A., Mons, R. \& Garric, J. Chironomus riparius solid-phase assay. Small-scale Freshwater Toxicity Investigations, Volume 1, eds. C. Blaise \& J.F. Férard, Springer Publishers Dordrecht, The Netherlands, pp. 437451. 2005.

[27] Borgmann, U., Norwood, W.P. \& Nowierski, M., Amphipod (Hyalella azteca) solid-phase toxicity test using high water sediment ratios. Smallscale Freshwater Toxicity Investigations, Volume 1, eds. C. Blaise \& J.F. Férard, Springer Publishers: Dordrecht, The Netherlands, pp. 413-436. 2005.

[28] Wells, P., K. Lee \& C. Blaise (eds.). Microscale testing in Aquatic Toxicology Advances, Techniques and Practice, CRC Lewis Publishers: Boca Raton, Florida, pp. 679, 1998.

[29] Persoone, G. Janssen, C. \& De Coen, W. (eds.). New microbiotests for routine toxicity screening and biomonitoring, Kluwer Academic/Plenum Publishers: New York, pp. 550, 2000.

[30] Blaise, C. \& Férard, J.F. (eds). Small-scale Freshwater Toxicity Investigations, Volume 1 (Toxicity test methods, 551 pages) and Volume 2 (Hazard assessment schemes, 422 pages), Springer Publishers, Dordrecht, The Netherlands, 2005. 